\title{
Modified Balance Scorecard Assessment of the cost of insecurity in the North Eastern Nigeria
}

\author{
Dr. Abdullahi Audu Malgwi
}

\begin{abstract}
This paper attempted to investigate the cost of insecurity in the North Eastern part of Nigeria. Modified Balance scorecard assessment of the cost of insecurity in the North Eastern Nigeria has been studied. The reason for the inquiry was to find out the cost implication to the region. Methodology utilized in conducting the study was through structured questionnaire and face to face interview with affected respondents. The data used in analyzing the study was obtained from opinion of respondents from the study areas. Modified Balance scorecard instrument was used to measure the cost implication of the insecurity in the region. The result showed that peace is yet to return despite the deployment of the military with the help of the civilian joint task force. The cost of the insecurity has completely paralyzed the economy, education, health and commercial activities in the region. The paper recommended for a change in gear in handling the situation.

Keyword: Balance scorecard, cost of insecurity and North Eastern Nigeria.
\end{abstract}

\section{Intorduction}

States that enjoyed peace are likely to achieve their target plans through budget enforcement and implementation. An inability of any state to maintain and control security situation would amount to destruction of lives, property and the economy. Lagos is one of the states in Nigeria that has relative peace and stability of good governance. Businesses flourish and boom with high influx of people of different nationalities and educational backgrounds. Poor and bad governance are attributes of bad leadership responsible for breakdown of law and order in a society. Politics of power maintenance and balance in leadership has derailed away the concept of good governance in Nigeria.

Borno, Yobe and Adamawa states have over some periods lost peace and tranquility. The cost implication of insecurity in these states has been assessed via balance scorecard to determine the quantum of damages to lives, properties and the economy. Right from the creation of these states, peace and tranquility was enjoyed in these areas, but now reverse is the order. Something concrete should be done to restore its lost glory.

\section{Methodology}

The methodology utilized in this study was the survey of opinions of people from the affected areas. Their opinions were obtained through questionnaire and face to face interviews. Instrument of data measurement was the modified balance scorecard. An ANOVA of the balance scorecard was run to obtain a confirmation of the mean range analyzed.

\section{THEORITICAL FRAMEWORK/LITERATURE REVIEW}

Kelechi and Osaze (2013) reported that any form of insecurity often creates fear and leads to lack of both human and other developmental projects. The slaughtering, killings, bombings and kidnappings of the activities of Boko Haram have created anxiety and fears in every hearts of those living in that region. The cost implications placed on government and individuals run into billions of Naira.

Proposed investors have shunned and change their decisions with regards to investments in these troubled areas. Most schools in the Boko Haram prone zones have closed down. Nigeria has lost colossal number of lives and properties in the North Eastern region (Baba, 2013). Lack of introduction of various schemes of benefits have lured the unemployed youth to engage in criminal activities .Some of the youth who do not want to go to formal schools often join the group called boko haram. Which means western education is forbidden, but they used all the things made in the western world. Illiteracy and ignorance is more pronounced in this region. Government should take a bold step to abolish all the informal schools run under trees and in front of houses. More sympathetic is the fact that so called educated parents also sends their children to such schools and their children resort to begging for food, clothing and other things.

Tom (2013) advocated for process accounting to track the record of such criminal acts and bring them to book. This can be done through blocking accounts of shady and unwarranted transactions. In a similar vein, Tiffany (2013) was of the opinion that managerial accounting with concrete quantitative and qualitative information should be brought into focus in order to track records of creditors of crime by controlling their plan operations. The social cost of insecurity include among other things rising cost of food and living standards, it 
is evident that quite a number of people in these regions are living from hand to mouth and could hardly afford three square meals. The government was aware of the happenings but her efforts could not restore normalcy to the region.

Eleanor (2012) observed that insecurity if not controlled could lead to uprisings, anxiety, fear and poor developments. It was observed that in Mexico and Central America, most of criminals and victims are young men in their youthful ages. In the North Eastern part of Nigeria, most of those associated with the Boko Haram groups are young men also. Leaders in Nigeria are undermining the destructive actions of these groups could do. Government of Nigeria requires leaders that could take the citizenry at heart by putting every effort to bring the matter under control

Sean (2013) lamented inability of government to employ the use of accounting information technology to track records of insurgents and their sponsors through financial institutions and commercial banks.

\section{Result And Discussion}

The data for the study has been collected and presented in the appendix. Mean range for consideration in this study is $\geq 2.5 \leq 2.5$. When the mean is $\geq 2.5$ imply that the number of people that lost their lives were so high and has slowed down the level of Business and other economic activities. Some activities and businesses have temporally stopped. When the mean is $\leq 2.5$ imply that businesses and activities have started to pick up gradually despite the frequent terror attacks on the citizenry.

The mean score and standard deviation of the data in table 1 was analyzed and presented below:

Scorecard counts mean standard deviation

$\begin{array}{llll}\text { People } & 6 & 3.16 & 1.169\end{array}$

Financial $\quad 6 \quad 2.00 \quad 0.632$

$\begin{array}{llll}\text { Learning/growth } & 6 & 0.83 & 0.258\end{array}$

Business process - $\quad \underline{\underline{6}} \quad \underline{\underline{0.75}} \quad \underline{\underline{0.273}}$

$\underline{\underline{24}} \quad \underline{\underline{6.74}} \quad \underline{\underline{6.332}}$

From the analysis, the highest mean (3.16) of the score comes from the people with a standard deviation of 1.169.P-value $=0.000$. The F-value of 16.32 confirms that the cost of the insecurity was so great. Some of the discussions from the respondents revealed that the insecurity lingered because it was support and funded by unknown group who supplies the insurgents with sophisticated weapons and breads at night by unknown means of shipment. The cost of the insecurity have cost others to leave those states while billions naira worth of properties destroyed, most of schools have been forced to close down and scanty services of medical care in some areas. The amounts so far compensated by governments to those who lost their lives and properties as a result of insurgents run into billions of naira which would have been utilized on developmental projects.

An interview with passengers who escaped from the hurts of insurgents lamented the disappearance of students of waka science secondary school and other passengers into the bush by the insurgents. The frequent slaughtering of passengers on roads into and out of Maiduguri had created fears into the hearts of those living in the affected areas. The recent attack on the military base in Maiduguri was a blow on the government for lack of adequate preparedness with modern fighting equipments. It appeared that government was trying to fight the insurgents with stick while it claimed to be among the best among African peace keeping mission. Nigerian papers and television broadcast often reports that peace and normalcy had returned to affected areas and workers in those place should go back to their work places. But this paper tagged such call as baseless and calculated to shade more blood by the insurgents.

The social cost of the insecurity has reduced social activities and has signaled to those who used to stay late night to be at home early. Virtually all activities that were done in the night have stopped because of fear of being attacked. Most of leaders handling and managing the insecurity are afraid or not sincere in actual report of the situation to the world.

It is now time to turn to the owner of lives and cry unto him for miraculous thing to happen to those fuelling, supporting and financing the crises. Growth and development of roads, education and hospitals in some areas have been paralyzed and skeletal services are provided. Business tycoons have sold their businesses to those without experience and have left those areas. The effect of such destruction of lives and properties will not be felt now until a decade to come. By then all professionals in any field of endeavor would have left those troubled areas. The citizens of those states would regret their actions but would be too late when the head is off. It is high time for those who conspire and brought this insecurity to repent because God is about to unfold his anger on the people of disobedience to his law. The law said "do not kill and he that kill shall die by the sword".

The cost of the insecurity has made the government to make provision for security in the 2014 budget at an amount of about N1.9 trillion. This amount would have been used for other developmental projects in Nigeria. Because of selfish interest of leaders, the North East is losing so many things to destruction of lives and 
properties. Instead to innovate and create things that would benefit the region, terrorism in the name of serving the evil one in order to gain power at all cost and maintains leadership position.

\section{Recommendation}

The study recommends that government should change tactics of handling the insurgents and proffer better options to create love for humanity and dignity. Orientation course and value for human lives and properties should be preached at all levels of government for peace and normalcy to return to those troubled areas.

\section{Conclusion}

The cost of insecurity in the North East has been surveyed and was found that peace and tranquility was yet to return. Billions of naira was lost through this form of terrorism.

\section{Appendix}

Insert table 1: Balance scorecard of respondents view on security accounting:

\begin{tabular}{|l|l|l|l|l|}
\hline Affected areas & People(4) & Financial(3) & Learning \& growth( 2) & Business process( 1$)$ \\
\hline Maiduguri & 3 & 2 & 1 & 1 \\
\hline Damaturu & 4 & 2 & 1 & 0.5 \\
\hline Mubi & 1 & 2 & 0.5 & 1 \\
\hline Baga & 3 & 1 & 1 & 0.5 \\
\hline monguno & 4 & 2 & 0.5 & 0.5 \\
\hline marte & 4 & 3 & 1 & 1 \\
\hline
\end{tabular}

Source: Field word, 2013.

Insert table 2: The ANOVA of the balance scorecard view is presented below:

\begin{tabular}{|l|l|l|l|l|}
\hline source & Sum of squares & df & Mean square & F \\
\hline Between & 23.3646 & 3 & 7.78810 & 16.32 \\
\hline within & 9.54167 & 20 & 0.477083 & \\
\hline Total & 32.9063 & 23 & & \\
\hline
\end{tabular}

Source: field work, 2013

\section{References:}

[1]. Baba,A(2013) the cost of insecurityinsecurity,http://www.businessdayonline.com/NG/index.php/analysis/editorial/

[2]. Eleanor, S (2012): Paying for crime. A review of the relationship between insecurity and development in Mexico and Central America

[3]. Kelechi A and Osaze O (2013): High cost of rising insecurity, http://theeeconomyng.com/news87.html.

[4]. Sean, C (2013): Network authentication, authorization and accounting. http://www.cisco.com/web/about/ac123/ac/147archived_issues/ipj

[5]. Tom R (2013): Process Accounting, http://www.freebsd.org/doc/handbook/security-accounting-html

[6]. Tiffany,C.W (2013): How do managerial Accounting systems contribute toward a company’s continual improvement? 